\title{
The Research of Historical Trusses in Northern Regions of Slovakia
}

\author{
Renáta Korenková, Peter Krušinský \\ University of Žilina \\ Civil Engineering Faculty, Department of Building Engineering and Urban Planning \\ e-mail: korenkova@fstav.uniza.sk, krusop@fstav.uniza.sk
}

\begin{abstract}
The blanket research of historical trusses in the territory of Slovakia has been running at our department since 2008. This research is done as teamwork in cooperation with experts from the field of conservation, and it is mainly focused on typology, construction, and the current technical and constructional state of investigated trusses. The long-time support of the grant scheme from the Ministry of Culture allows to get a fair amount of different data related to individual buildings and structures, which enables to carry out the in-depth research. In terms of their conservation and maintenance with an effort to extend their lifetime (the oldest known historical trusses in Slovakia are those of the 13th century), it is necessary to look into the microclimate impact of the under-roof space on wooden roof structures as well as to monitor the contemporary constructional and technical condition of a roof structure itself. The suitable microclimate in the under-roof space is influenced by a number of marginal conditions, constructional solutions of roof details, proper space ventilation etc.
\end{abstract}

Key words: historical trusses, technical state, wooden structure, cultural monuments, parametrically analysis

\section{Introduction}

Under the constructional and historical research of historical trusses, made in northern regions of Slovakia, the preliminary structural and technological research was also realized. Each of investigated objects is documented in detail, and all information connected with their technical condition, historical and typological classification, locations, and particular interventions was recorded. Information obtained from these studies is being subsequently processed into an overall database with running results processing. This article pays attention to define the area of interest in the historical trusses. This area provides the space for detailed analyzing of data complex which forms the research results. 


\section{The area of interest}

Historical roofs in northern regions of Slovakia, namely in regions of Orava, Kysuce, and Turiec $[1,2]$, are items of interest of this paper - (figure 1). The entire research also deals with regions such as Liptov, Bytča, Žilina, and partially Upper Ponitrie as well as Gemer. Until now, about 460 historical trusses have been documented. These studies are chiefly carried out in sacral buildings; secular buildings, especially aristocratic residences, citizens' houses or administrative buildings are smaller representatives of documented trusses (figure 2). It is connected especially with the permission for entering the object. Church buildings were the simplest to enter in contrast to private objects where most of their owners didn't agree with the entry into the truss.

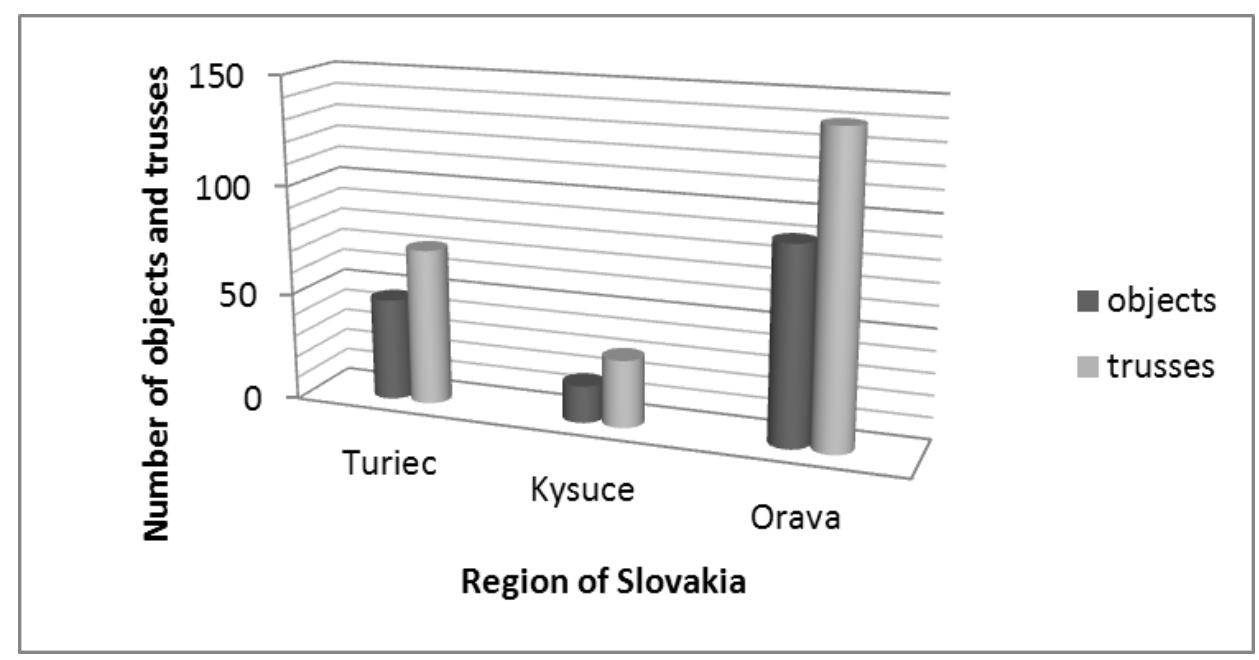

Figure 1: Representation of objects and trusses analyzed in the research of historical trusses

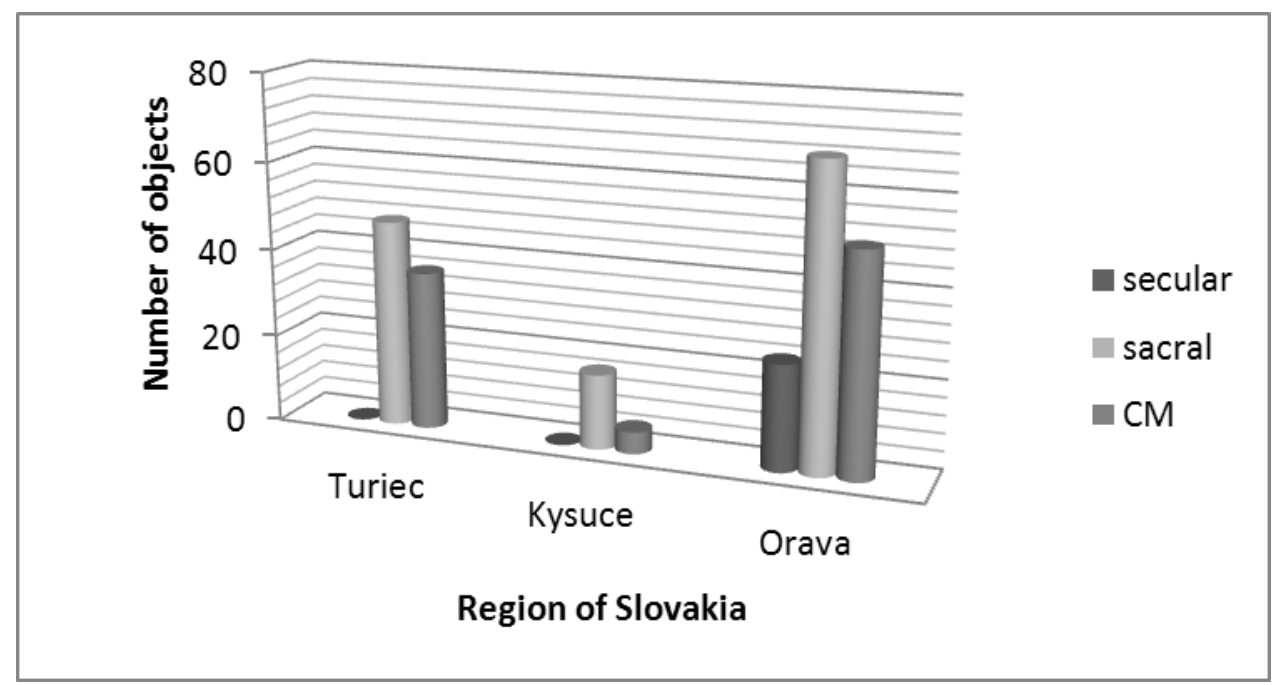

Figure 2: Representation of particular object types analyzed in the research - sacral, secular. The number of objects is shown as Cultural Monuments (CM) 
This contribution brings analysis of 243 trusses in 154 buildings. It includes 72 trusses in the Turiec region, 31 trusses in the Kysuce region, and 140 trusses in the Orava region. The shares are as follows $-85.7 \%$ of sacral buildings, and $59 \%$ of cultural monuments; the amount differs regarding individual regions $-55 \%$ in the Orava region, and only $5.5 \%$ in the Kysuce region.

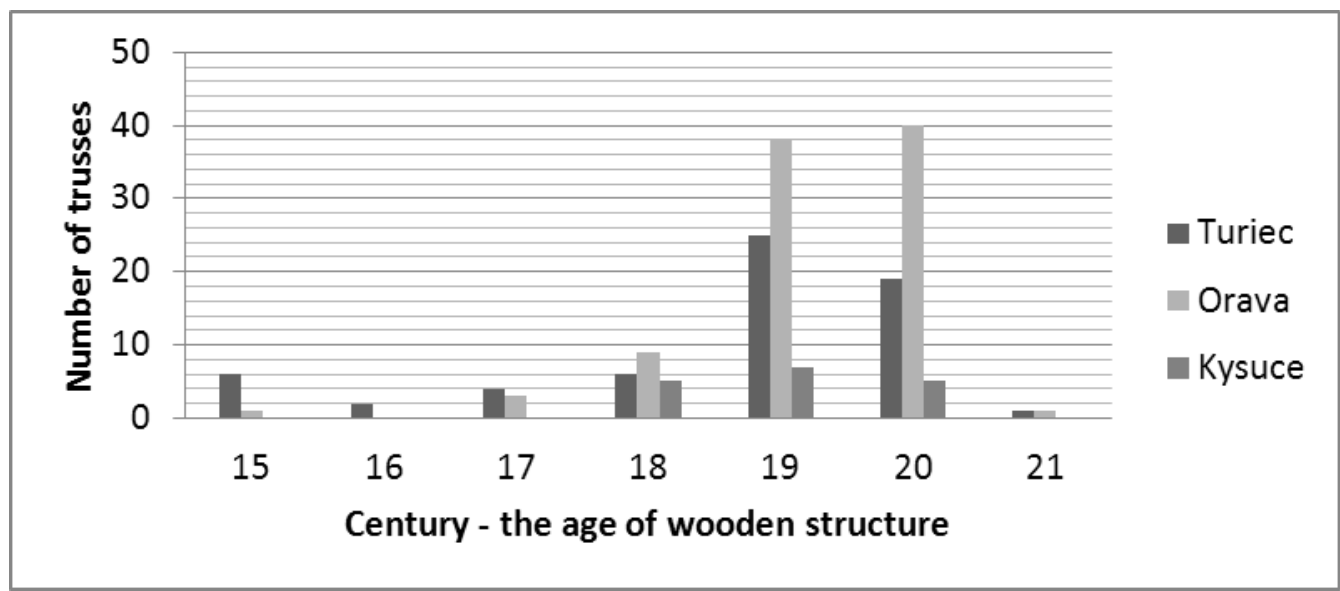

Figure 3: Historical trusses that were analyzed in selected regions of Slovakia aligned according to the century (the age of wooden structure by dendrochronological dating)

The charts above show that the oldest historical structures of trusses are found in the region of Turiec. The oldest truss in the village of Belá-Dulice (Turiec) is dated from 1409d. The youngest structures are found in the region of Kysuce where the oldest truss is dated from 1758-59d.

\section{Roofs structures}

In accordance with professional studies and literature published in Slovakia as well as abroad dealing with the problem of historical trusses [3], historical climatology [9], and history of geometry [10] it is possible to suppose the certain dependence of a truss structure slope in the roof plane area, and the style period wherein the particular truss was built, notably in relation to long-time climate changes, the principle development of structural systems [11], and other largely social influences. The database obtained during our studies in selected regions also shows some dependence, while it is necessary to take into account time spread and the shift of typological and structural classification in respect to style periods, as well as social events.

Figure 5 shows different roof types according to their shape. The occurrence of hipped roofs representing the traditional shape of sacral objects for the sanctuary roofing is the most common.

When the lifetime of original roofing material ends, this is often replaced during the renovation of a historical truss. The guidance for preservationists plays an important role in such a process, because they are authorized to choose suitable roofing considering the architectural and historical research. The financial capacity of an investor as well as his suggestibility by advices from "practitioners and implementers" is also one of important 
points related to the renewal, due to unawareness of original system functions, sometimes with negative impacts on the structure itself.
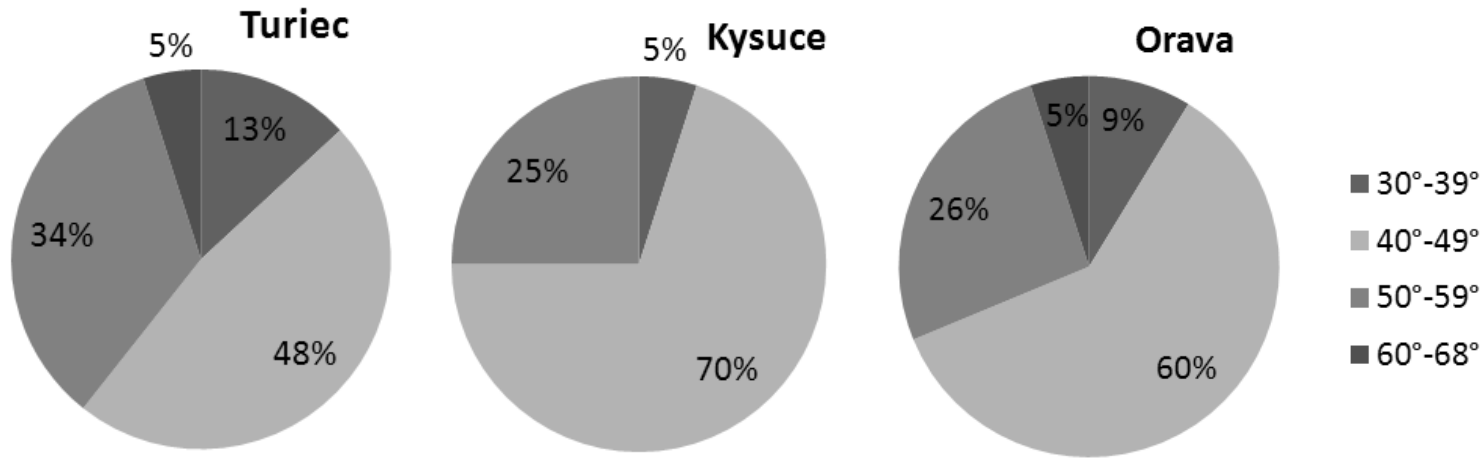

Figure 4: Roof representation in selected regions according to the roof plane slope

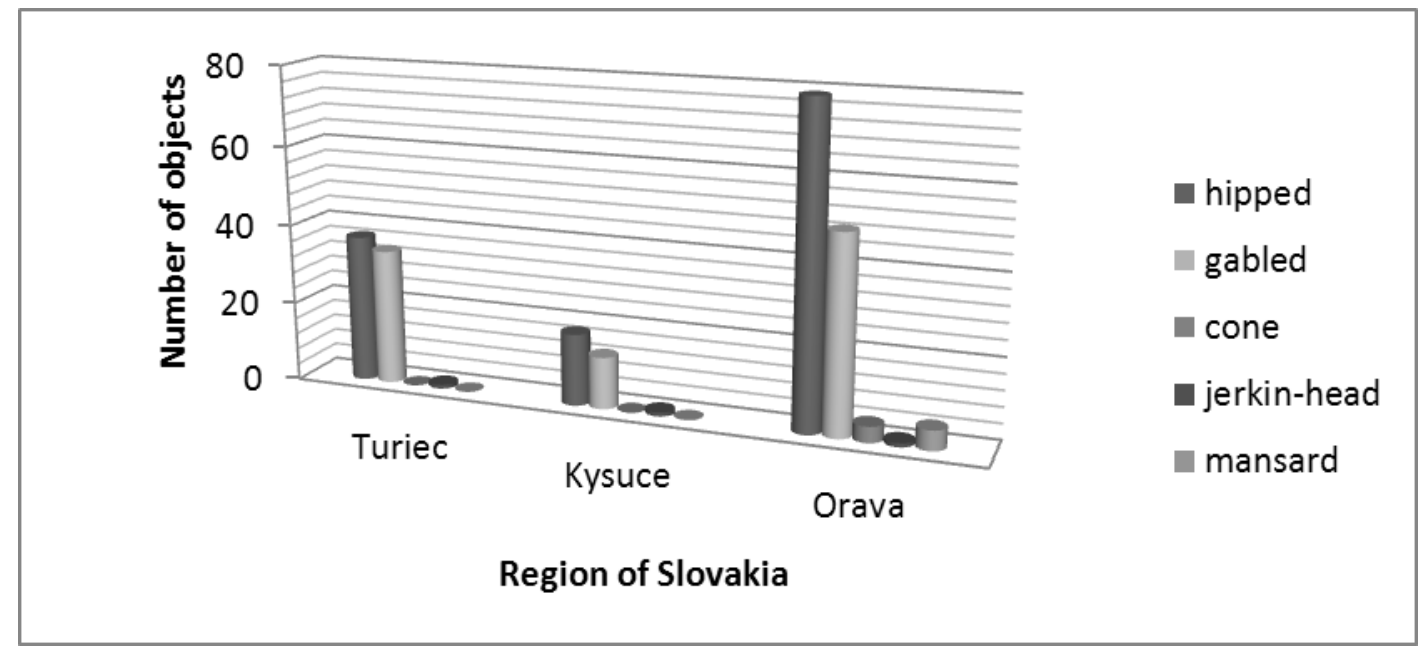

Figure 5: Representation of different roof types according to the roof shape in investigated regions of Slovakia
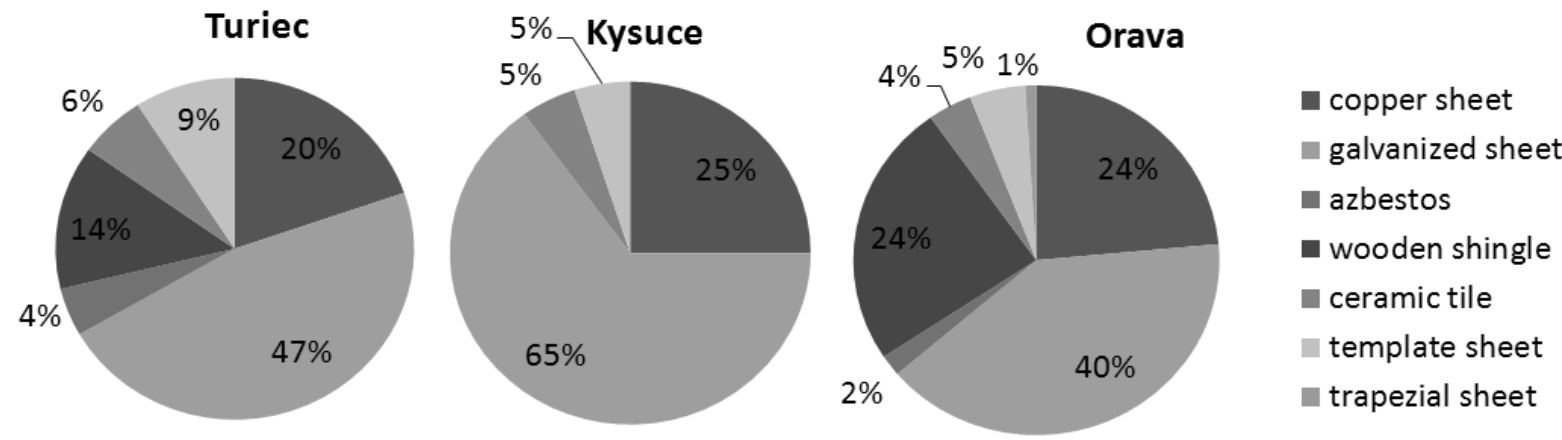

Figure 6: Representation of roofing types used in selected regions - as a percentage 

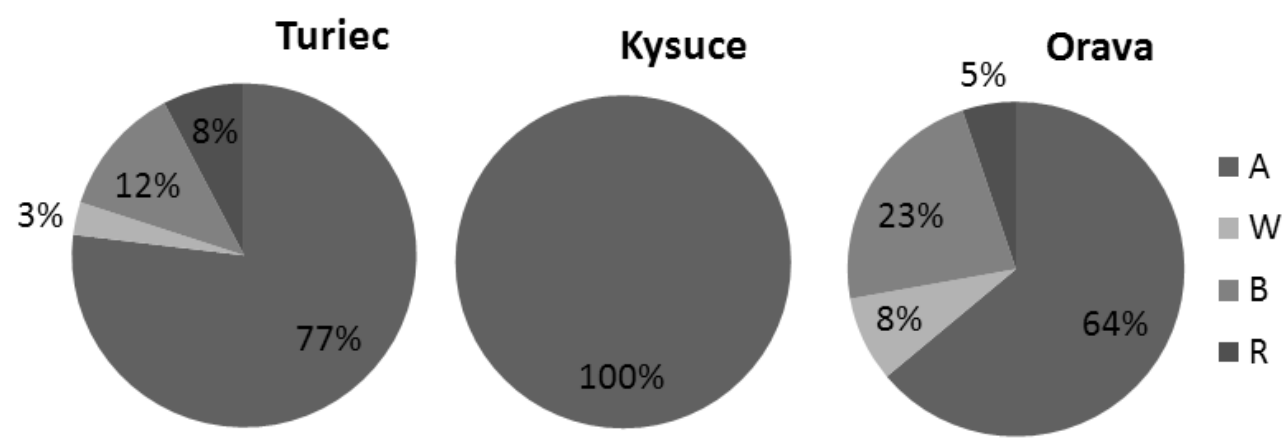

Figure 7: Representation of floor structure types in selected regions:

A - heavy arches, W - wooden arches, B - ceilings of wooden beams, R - ceilings of reinforced concrete

Individual types of roofing are shown in Figure 6. The figure also shows that galvanized sheet roofing is the most frequent. The copper sheet is in the second place, and a wooden shingle is the third one. Ceramic tiles are used in $7 \%$ of investigated trusses. Use of different types of floor structures was also documented in evaluated historical trusses. As seen in Fig. 7, heavy arches (brick, concrete) belong among the most frequent ones.

The roof deck of a historical truss usually consists of roofing on an auxiliary structure. Currently, it is often applied an under-roof foil, which serves as additional water-proofing too, during its exchange. As for investigated trusses, roof foils were applied in $7.6 \%$ of cases. But the foil was not used properly, often with faults at its realization, in almost $23 \%$ of cases, which led into various defects.

Historical trusses are also renovated due to energy saving, which leads to thermo-insulating of arches, or ceilings over the last floor (including the under-roof space of a historical truss). Thermo-insulation is freely put on the floor surface, and it usually consists of mineral wool, but there were also perlite layer causes recorded. The upper surface of thermo-insulation used to be covered with paper, or a foil. There was only a foil freely put on the floor in $1 \%$ of cases, and as for wooden arches there was a board used in almost $2 \%$ of cases. The way of putting thermo-insulation can differ; very often it has various measure of degradation. In some cases - about 1\%, thermo-insulation was also put on arch ribs, or on protruded walls.

\section{Truss structure}

The representation of individual structural systems in historical trusses was also accounted under the entire analysis of regions. System division is indicated in accordance with the basic general knowledge. That is, only a basic constructional scheme is shown which doesn't take into account the more detailed typological division of trusses according to particular periods with their typical details. System division: 
A. Common rafters trusses:
a. Simple without longitudinal bracings
b. Simple with longitudinal bracings
c. With a collar beam without longitudinal bracings
d. With a collar beam with longitudinal bracings

B. Purlin trusses - traditional
a. With a hanging posts
b. With a standing trestle
c. With a leaning trestle
d. Purlin system
e. With a strut

The truss system "A" is typical for older historical frameworks. System "B" is characteristic for the traditional truss system. Both groups of systems were used for the evaluation of obtained database. Trusses that can be classified as a group of modern structures represent about $6 \%$ of the total number of analyzed truss structures. Modern roofs are characterized using a collet, or purlin, and they have been significantly associated with the construction and renovation since 1945 .

Information on the number of investigated trusses is shown in Figure 8 . There were 222 trusses evaluated of all their quantity. Rafter truss systems represent $57 \%$, and purlin systems comprise $43 \%$. The comparison of the use of individual systems in selected regions indicates that the largest occurrence of rafter trusses is recorded in the region of Orava - 53\%, 30\% in the region of Turiec, and $17 \%$ in the region of Kysuce. As to purlin systems, the situation is similar; there are $60 \%$ of them in the region of Orava, $31 \%$ in the region of Turiec, and $9 \%$ in the region of Kysuce. From the regional evaluation it is clear that there are $55 \%$ of rafter trusses, and $45 \%$ of purlin systems in the region of Turiec. The share of rafter systems is $54 \%$, and the share of purlin systems is $46 \%$ in the region of Orava. The region of Kysuce has $71 \%$ share of rafter trusses, and $29 \%$ of purlin systems.

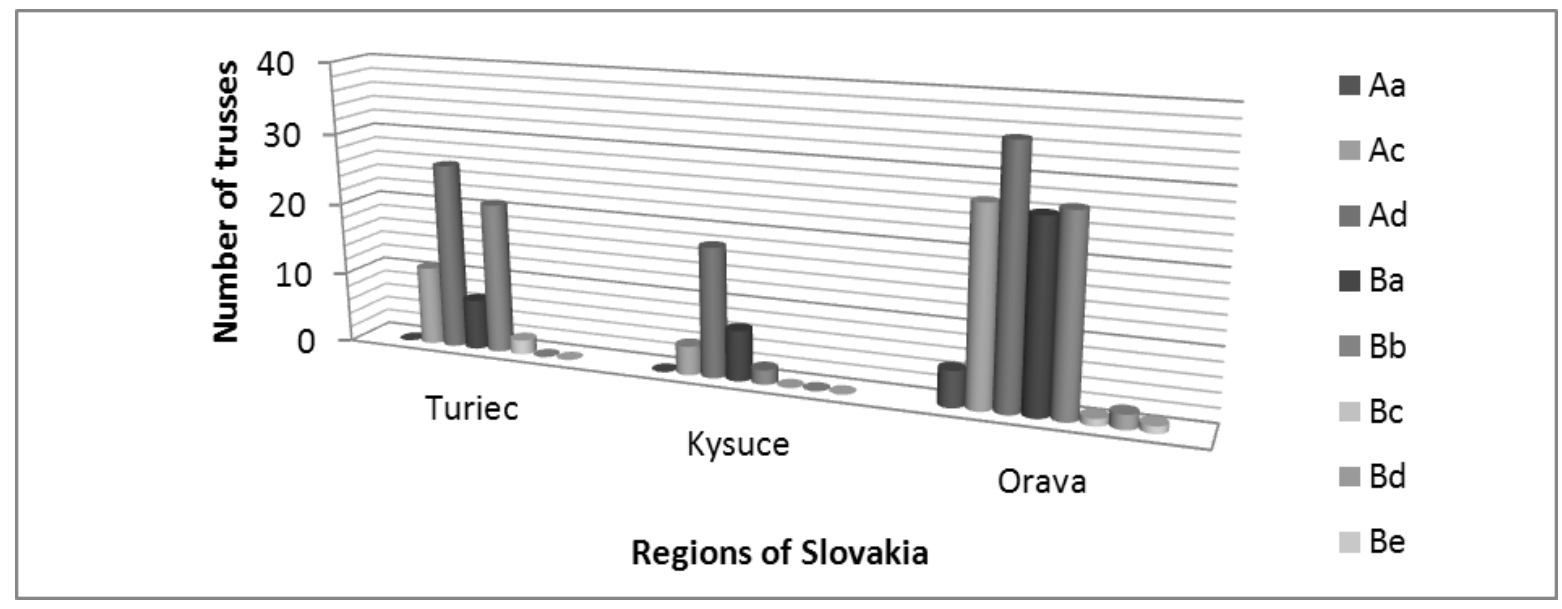

Figure 8: The basic division of structural systems in selected regions of Slovakia 


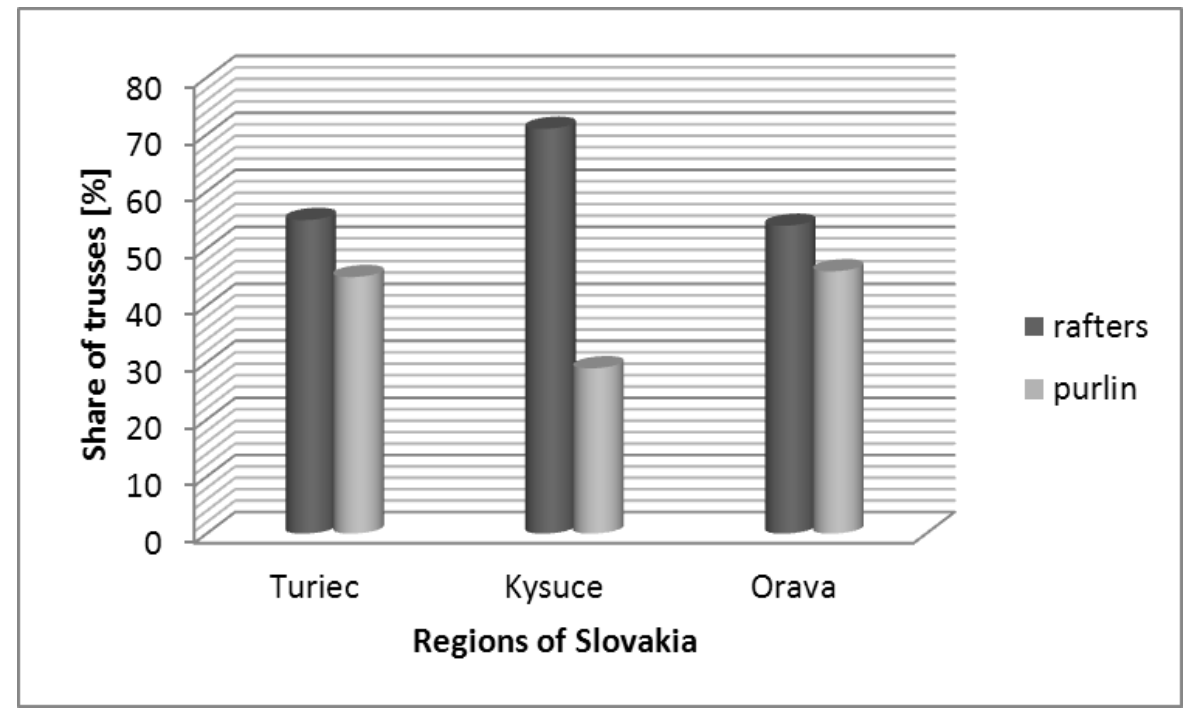

Figure 9: The share of rafters and purlin structural systems in selected regions of Slovakia

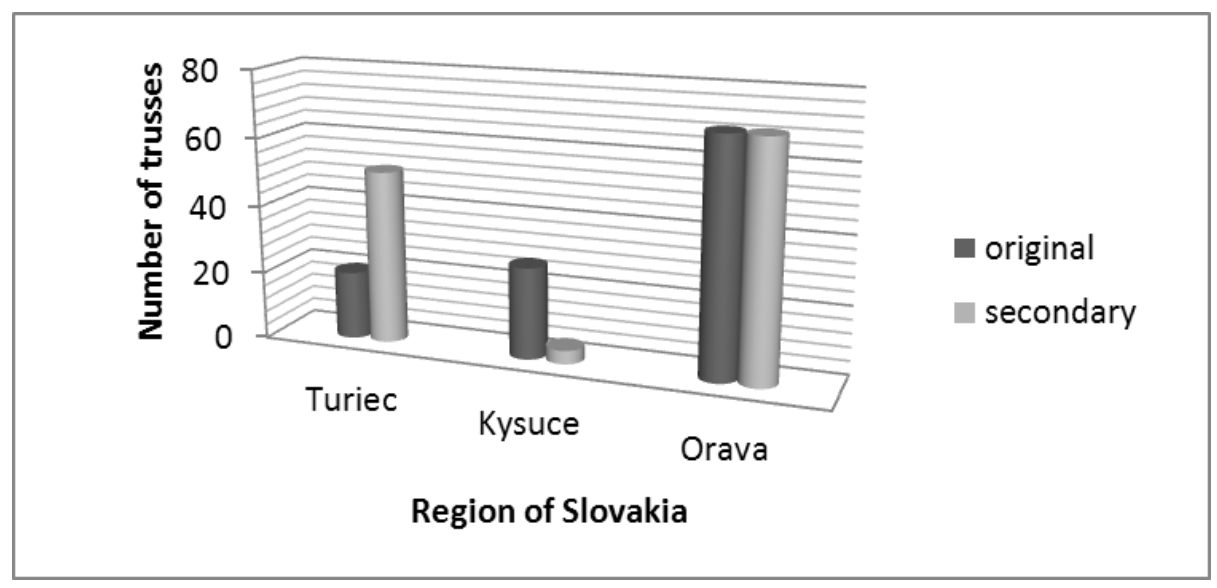

Figure 10: Representation of historical trusses from the view of their originality regarding the period of the church construction

Structural authenticity of historical roofs is one of the important factors in designing renewals and redevelopments of these structures [12]. From the perspective of the conception of conservation, it is necessary to know the value of particular structures not only due to their primacy but also due to their age, method and tree species used in past renewals. Figure 10 indicates that most of original truss structures are found in the region of Kysuce wherein there are few originally medieval buildings (they are located in Lower Kysuce - the district of Kysucké Nové Mesto), which is associated with the system and the way of regional settlement. The main building material in Kysuce was wood which was later replaced with masonry constructions. Referring to the relatively high number of medieval sacral buildings (the 13th - 14th century), there is the considerable share of secondarily truss structures in the region of Turiec [8]. Mostly structural modifications of buildings (extensions, additionally inserted arches, historical events ...) influenced their exchanges significantly. 


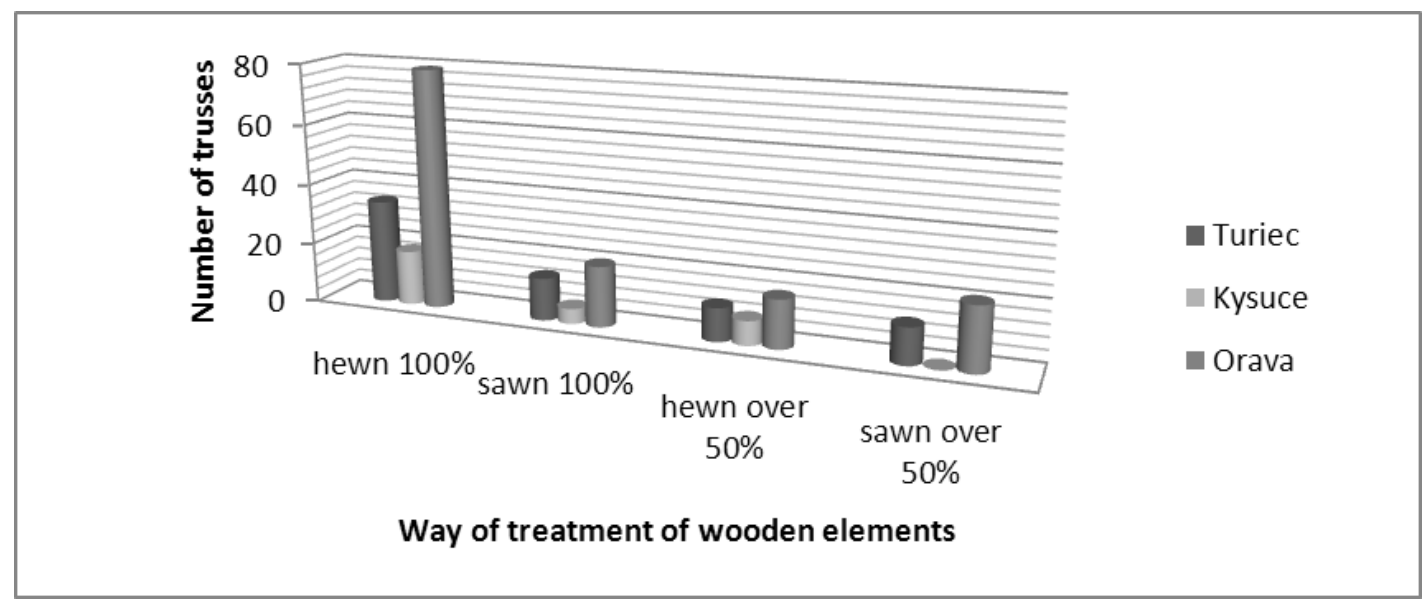

Figure 11: Ways of working of wooden elements

Looking at the figures above (Figure 11) it is obvious that trusses with wooden hewn components are the most frequent with their predomination in the Liptov region. Logging and processing of wood was one of essential economic activities in Orava, and wood was a basic building material there for a long time. Buildings with preserved original trusses are mainly dated from the 18th and 19th century (Upper Orava), and possibly the truss renewal or its exchange happened in the period of time when technologies for industrial processing of wood were not developed yet (the 18th century and the first half of the 19th century).

\section{Conclusion}

Results of particular analyses can be summarized into following points:

- The number of investigated trusses is higher than the number of buildings; it arises from the use of separate constructions, e.g. the trusses over a nave and sanctuary that are often divided with a gable wall.

- The lower number of profane objects (about 14.3\%) follows from refusing the entry into trusses mainly by private owners (problems in property relations).

- The total high share of constructions dated from the 19th and 20th century follows from building activities, mostly in the regions of Upper Orava and Upper Kysuce (transition from whole-wooden to masonry buildings, and also from frequent building modifications after the fire when a new truss structure was required).

- The total high share of roofs with a slope of $40^{\circ}-49^{\circ}$ (about 36\%) is clear from the high share of structures dated from the 19th century and the turn of the 19th and 20th centuries.

- The hipped roofs predominate (about 55\%) in studied regions, which is probably related to the age of trusses.

- Nowadays, galvanized sheet is used for roofing very often (about $51 \%$ ); the main reason is roofing exchange after its lifetime in combination with its price availability during its renovation. Most of roofing exchanges happened after 1945. 
- The high share of stone and brick floors (about $80 \%$ ) is a consequence of the age of building itself as well as continuous economic growth in all individual regions.

- Predominated structural scheme with collar beam and longitudinal bonding is associated with the width of investigated objects for which this structural type is optimal; this is not influenced by the age of structure, or the period when it was built. The share of rafter trusses is $57 \%$ in total.

- The small difference between primary and secondarily structures is the result of the age of investigated buildings, the way of area settlement in mentioned regions, their economic development, and historical events. The share of original structures is $48.3 \%$, the share of secondarily ones to the age of building is $51.7 \%$.

- The total higher amount of hewn truss structures is related to the period of their construction, the long-time tradition in hand working, and the economic situation in involved regions. The share of fully hewn structures is $55 \%$, and there are $16 \%$ of sawn structures. The rest is formed by their combinations.

Data obtained from grants that have been realized since 2008 regarding particular regions were used for creating the database which provides wide potential for analyzing and finding mutual connections among individual parameters. Existing results statistically prove, or confirm facts that can contribute to the sustainability of unique historical structures in a large measure [6]. Dependences that seem to be very important are e.g. changes and modifications in the usage regime of a building in relation to the biotic damage of trusses, and also influences that can cause such damage $[4,5,13]$. Outputs of statistical data processing can markedly help in creating the renewal methodology of historical buildings, and they can make a contribution to the preservation of cultural heritage for future generations [7].

\section{Acknowledgements}

This contribution is the result of the project implementation: " VEGA 1/1296/12 Geometric analysis of historical roof construction of territory SR/ Geometrická analýza historických krovových konštrukcií z územia SR.

\section{References}

[1] Suchy, L., Krusinsky, P., Grunova, Z., Durian, K., Zacharova, D. \& Korenkova, R. (2010). Historical Trusses in the Regions of Orava and Kysuce. Zilina: M. Gibala KNM. (published in Slovak language).

[2] Suchy, L., Krusinsky, P., Babjakova, Z. \& Durian, K. (2008). Historical Trusses of Sacral Buildings in the Turiec Region. Zilina: Publisher M. Gibala KNM. (published in Slovak language).

[3] Vinar, J. \& Kufner, V. (2004). Historical Trusses - their Structure and Statics. Praha: Grada (published in Czech language).

[4] Korenkova, R.(2012). Analysis of Roof Spaces in Historical Trusses. In: 36. Mezinarodni vedecká konference kateder a ustavu pozemniho stavitelstvi, 19-21 September 2012 (pp. 49-52). Brno: VUT Brno (published in Slovak language). 
[5] Korenkova, R.(2011). Remediate modification of historic roof trusses in region Liptov. In: Theoretical foundation of civil engineering : XX Polish - Russian - Slovak seminar, 05-10 September 2011 (pp. 395-400). Warszawa: University of Zilina.

[6] Korenkova, R. \& Krusinsky, P.(2012). The analysis of moisture regime of the under-roof space in historical truss. In: Theoretical foundation of civil engineering: XXI Russian - Slovak - Polish Seminar, 03-06 July 2012 (pp. 297-302). Arkhangelsk: Politechnika Warszawska.

[7] Kotlinova, M., Kloiber M. \& Blaha J. (2008). Prevention: the best remedy. All about wood in the interior and exterior. (pp. 157-160). Bratislava: Jaga Group (published in Czech language).

[8] Krusinsky, P., Korenkova, R., Grunova, Z. \& Suchy, L. (2013). Gothic Trusses in the Liptov Region. In: Strechy-Fasady-Izolace, 20 (1), 30-32. Ostrava: Mise (published in Slovak language).

[9] Behringer W. (2010). The Cultural History of Climate. Praha: Paseka. (published in Czech language).

[10] Vopenka P. (2000). The Cornerstone of European Culture and Power. Praha: Prah (published in Czech language).

[11] Capkova, E. \& Krusinsky, P. (2012). Geometric analysis of the Gothic Roman Catholic Church Truss in the Village of Bela Dulice. In: IX. international scientific conference FCE TUKE: organized on the occasion of the 35th anniversary of the Faculty of Civil Engineering and the 60th anniversary of the Technical University of Kosice, 22-25 May 2012. Kosice, Slovakia: TUKE. (published in Slovak language).

[12] Izvolt, P. (2006). Save Historical Trusses. All of the Roof. Bratislava: Jaga Group (published in Slovak language).

[13] Rodriguez Linan, C., Morales Conde, Ma J., \& Rubio de Hita, P. et al. (2011). Inspeccion with non destructive techniques of a historic building: oratorio San Felipe Neri (Cadiz). Informes dela Construccion, 63 (521), 13-22. DOI: 10.3989/ic.10.032. 